\title{
Rumah Inti untuk Percepatan Rehabilitasi dan Rekonstruksi Pasca Bencana bagi Masyarakat Pedesaan
}

\author{
Agam Marsoyo
}

The core house as instead of the tent in rehabilitation and reconstruction process for villagers who have undergone natural disasters is neede so that they can return fo normal life and they have a good future. The recovery process of the core house after disaster actually is not easy in particular because of the limited fund resources. Thus, it needs to be capitalized by the other capital resources in that process, for instance social capital. The core house building and trnsforming in the villagers area needs community who have social capital to accelerate its existence.

Kata Kunci: Bencana, Pedesaan dan Rekonstruksi

onsep pembangunan dan pengembangan rumah pada dasamya bukanlah suatu konsep yang baru. Konsep ini sebenarnya telah berkembang sejak tahun 1970an. Ketika itu John N. Habraken, dkk (1976) dan John Tumer (1976) memperkenalkan suatu alternatif pembangunan perumahan sebagai sesuatu yang fleksibel, dinamik, dan kegiatan yang incremental. Kedua tokoh ini seolah-olah mendobrak suatu tradisi produksi perumahan (production of houses) yang serba jelas dan pasti yang dikendalikan oleh faktor ekonomi atau pendekatan efisiensi belaka yang dimotori oleh pemerintah. Namun demikian, keduanya mendobrak tradisi lama itu, ternyata Habraken lebih melihat mikro daripada Tumer yang menekankan pada aspek makro. Makro yang dimaksud disini adalah pada dukungannya pada perbaikan kebijakan pemerintah dan intervensi langsung para profesional. Sementarà yang dimaksud mikro adalah pada perbaikan lingkungan fisiknya. Walaupun kemudian beberapa aktor pembangunan perumahan menekankan adanya self-help housing yang intinya menekankan pada penghuninya sendiri.

Dalam kaitan pembangunan rumah bagi masyarakat yang terkena bencana dan mayoritas masyarakat miskin, konsep di atas memang masih relevan untuk diangkat ke permukaan. Hal ini mengingat dengan adanya pendekatan klasik yang serba disediakan (housing supply), model penyaluran yang terpusat, yang formal, dan kaku sudah tidak tepat untuk diimplementasikan kecuali bila memang pemerintah memiliki dana yang cukup. Untuk itulah konsep pengembangan rumah inti ini ditulis dan telah diujicobakan di wilayah Imogiri Bantul Yogyakarta pada bulan Agustus sampai dengan Oktober 2006. Tulisan ini tidak memisahkan bagian konsep dengan bagian implementasi-praktis namun diulas dalam kemasan yang memudahkan untuk dipahami. 


\section{Konsep Rumah Inti dengan Dasar Modul}

Rumah inti pada dasarnya muncul sebagai akibat adanya kekurangan rumah dan sebagai jawaban untuk memenuhi kebutuhan rumah (housing demand) yang banyak di perkotaan negara-negara berkembang dengan penghasilan penduduk per kapitanya rendah dengan relatif cepat. Konsep rumah inti, yang kemudian ada yang menyebutkannya dengan core house atau small house, dan bahkan ada yang menyebut hanya shelter, telah berkembang sejak tahun 1960-an. Sebenarnya istilah rumah inti yang paling tepat adalah sebagai shelter, karena shelter sebagai kebutuhan pokok manusia yang akan melindungi dari berbagai faktor luar (Patton, 1988). Shelter ini dikembangkan oleh Charles Abrams (1964) dengan gagasannya yang hanya menyediakan kerangka rumah beserta atapnya tanpa ada dapur dan kamar mandi. Konsep ini kemudian dikembangkan lagi oleh John $\mathrm{N}$. Habraken (1976) dengan detachable unit sebagai pengisi struktur misalnya dinding.

Pada mulanya, berdasar konsep di atas, core house terdiri dari dua kamar tidur yang masing-masing seluas $8 \mathrm{~m}^{2}$, sehingga total luas core house hanya $16 \mathrm{~m}^{2}$. Dalam perkembangannya, luas core house atau rumah inti berkisar antara $12 \mathrm{~m}^{2}$ sampai dengan $21 \mathrm{~m}^{2}$.

Pengertian struktur fisik dalam disiplin ilmu bangunan adalah komponen yang utama dalam bangunan. Struktur inilah yang akan menyangga bangunan sehingga kokoh berdiri. Hanya kemudian struktur ini harus mengikuti sistem yang ada, artinya komponen utama bangunan itu haruslah berkait satu dengan yang lain sehingga menjadi kokoh. Inilah yang disebut dengan sistem struktur yang tertutup. Sistem ini mengkaitkan antara struktur kolom (komponen utama yang vertikal), balok ring (komponen utama horisontal di bagian atas), dan sloof (horisontal di bagian bawah). Kritik terhadap bangunan masa lalu yang tidak mengikuti sistem struktur yang tertutup inilah yang menyebabkan banyaknya bangunan rumah menjadi tidak kokoh dan labil ketika terjadi goncangan gempa.

Lalu apa hubungannya antara strukfur bangunan tersebut dengan modul? Itu pertanyaan yang muncul ketika rumah inti akan dibangun. Modul merupakan unit terkecil yang paling efektif, efisien dan fleksibel baik dari sisi fungsi maupun dari sisi bahan bangunan. Modul ini digunakan sebagai dasar menentukan dimensi ruang dan komponen-komponen fisik ruang dalam bentuk kelipatannya. Komponen-komponen fisik ruang yang tergabung menjadi struktur bangunan, dalam pandangan ini, mengikuti dimensi ruang fungsional. Modul yang digunakan pertama kali adalah modul ruang fungsional dan diikuti oleh modul struktur bangunan. Dari berbagai literatur menunjukkan bahwa modul ruang fungsional sebuah kamar tidur sederhana berdimensi $3 \mathrm{~m} \times 3 \mathrm{~m}$ sampai dengan $3 \mathrm{~m} \times 3,1 \mathrm{~m}$. Derni kemudahan untuk diingat digunakanlah modul $3 \times 3 \mathrm{~m}^{2}$, dan kelipatannya bisa menjadi $3 \times 6 \mathrm{~m}^{2}, 6 \times 6 \mathrm{~m}^{2}, 6 \times 9 \mathrm{~m}^{2}$, dan seterusnya. Sementara itu, modul untuk komponen bangunan mengikuti modul dasar $1 \mathrm{M}$ yang berarti sebesar $10 \mathrm{~cm}$. Hal ini berdasarkan rekomendasi Intemational Organization for Standardization (ISO) Nomor 1006 tahun 1989. Dengan sistem koordinasi modul tersebut, sebenarnya antara modul struktur dan modul ruang fungsional tidak menjadi masalah. Bila unit terkecil adalah $3 \mathrm{~m} \times 3 \mathrm{~m}$, maka untuk rumah inti adalah $3 \mathrm{~m}$ $x 6 m$ atau seluas $18 m^{2}$ dan telah diujicoba beberapa unit di wilayah Imogiri Bantul (Lihat Gambar 1). 

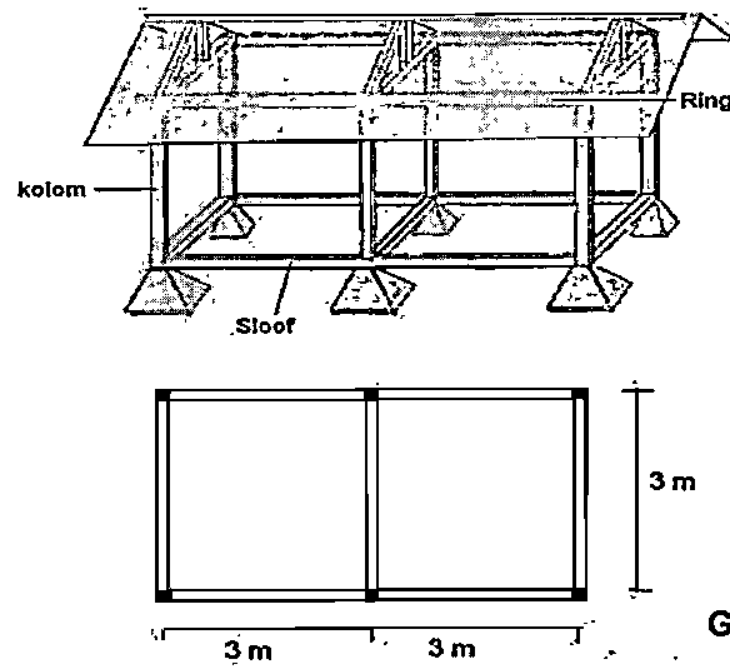

Gambar 1.: Rumah lnti $3 \times 6 \mathrm{~m} 2$. Sumber: Tim PSPPR-UGM, 2006

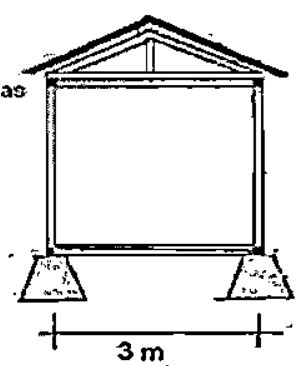

Rumah Inti $3 \times 6$ m. 2 (Häryà. struktur'rangka saja):

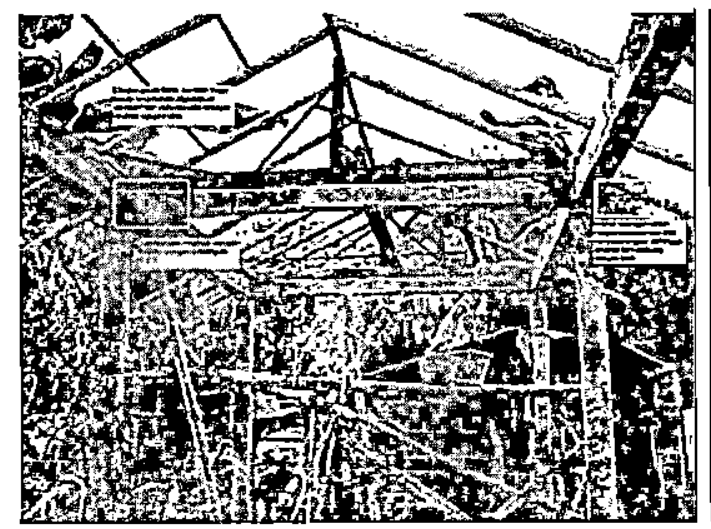

\section{Gambar 2. : Proses pelaksanaan Rumah Inti Moduler di Imogiri Yogyakarta, Agustus 2006}

Dalam proses membangun rumah pada umumnya bisa dilakukan secara pabrikasi (segalanya dibuat oleh pabrik dan di lokasi hanya merangkai menjadi rumah), semi pabrikasi (beberapa komponen bahan dikerjakan oleh pabrik dan sebagian lainnya dengan cara konvensional di lokasi serta cara pencetakan bahan di tempat misalnya cetakan konstruksi beton), dan cara konvensional (semua komponen bangunan tersebut dikerjakan di lokasi). Cara yang sering muncul adalah cara semi-pabrikasi karena berbagai pertimbangan yang salah satunya adalah karakteristik lokasi yang berbeda-beda sehingga memerlukan cara pengerjaan yang konvensional melihat situasi dan kondisj fisik lokasi yang ada. Demikian juga dalam proses pembangunan rumah inti $18 \mathrm{~m}^{2}$ untuk korban bencana yang tidak bisa hanya menggunakan cara pabrikasi dan cara 
konvensional tetapi dengan pertimbangan karakteristik lokasinya, maka yang baik adalah cara semi-pabrikasi. Dari cara ini pulalah pemikiran tentang modul menjadi salah satu faktor penting. Dengan demikian pembangunan rumah inti untuk korban gempa perlu memikirkan dimensi-dimensi komponen bahan yang dikeluarkan oleh pabrik.

Waktu pembangunan rumah inti semipabrikasi per 1 unit hanya memerlukan 5 hari. Waktu tersebut sudah mempertimbangkan dengan cara-cara pembangunan cetakan beton di tempat dan dilaksanakan oleh minimal 5 tenaga kerja. Namun bila dikerjakan secara massal, dan masyarakat yang bergotong-royong semakin banyak, waktu tersebut bisa lebih sedikit. Lama pernbangunan tergantung pula pada aktivitas masyarakat serta ketersediaan bahan bangunan.

Biaya pembangunan satu unit dihitung hanya untuk bahan struktur dan konstruksi sebanyak kurang lebih Rp.3.500.000,-. Biaya tersebut tidak termasuk ongkos tukang, dan biaya pembuatan cetakan konstruksi serta peralatan lain. Bila ongkos tukang diperhitungkan, maka diperkirakan akan mencapai kurang lebih Rp.5.000.000,per unit.

\section{Pengembangan Rumah Inti Moduler}

Pengembangan rumah inti moduler dalam pengertian ini adalah rumah inti yang dikembangkan oleh pemiliknya atau oleh pihak lain dengan mengikuti atau meneruskan pola-pola rumah inti. Konsep pengembangan ini juga disosialisasikan pada masyarakat penerima rumah inti agar mereka bisa memperkirakan kemana pengembangan rumahnya kelak. Pengembangan rumah (housing extension atau housing transformation) memiliki pengertian tidak hanya horisontal tapi juga vertikal. Pengembangan rumah inti memberikan banyak keuntungan bagi penghuni antara lain kebutuhan ruang untuk kegiatan di dalam rumah semakin tercukupi. Di samping itu, dengan pengembangan atau pènambahan rumah memberikan kemungkinan baru dan usaha-usaha baru di dalam rumahnya seperti munculnya usaha warung, kelontong atau biasa disebut dengan rumah usaha atau home-based enterprises (Tipple, 1996, 2000; Sinai, 2002).

Graham Tipple (2000) lebih lanjut berpendapat bahwa pengembangan rumah (housing transformation) memiliki variasi yang sangat banyak. Variasi tersebut dikelompokkan oleh Tipple menjadi pengem-

Tabel 1. Detail Biaya Pembangunan Satu Unit Rumah Inti

\begin{tabular}{|l|l|l|}
\hline No & Spesikasi & Harga kasar \\
\hline 1 & Pengerjaan pondasi setempat & Rp. $430.000,-$ \\
\hline 2 & Pengerjaan kolom & Rp. $520.000,-$ \\
\hline 3 & Pengerjaan sloof & Rp. $700.000,-$ \\
\hline 4 & Pengerjaan ring (atas) & Rp. $700.000,-$ \\
\hline 5 & Pengerjaan rangka atap dan penutup atap seng & Rp.1.150.000,- \\
\hline & \multicolumn{1}{|c|}{ Jumlah } & Rp.3.500.000,- \\
\hline
\end{tabular}

Sumber: Tim PSPPR-UGM, Agustus 2006. 
bangan yang sederhana dan kompleks. Pengembangan rumah yang sederhana hanya menambah luas luas tanpa banyak merubah denah rumah aslinya. Sementara pengembangan yang kompleks meliputi penambahan ruang-ruang bisa horisontal maupun vertikal yang lebih rumit.

Dalam kasus pengembangan rumah inti moduler yang dikembangkan di Imogiri belum terlihat proses pengembangannya. Proses pengembangannya memang akan diserahkan pada penghuni sendiri dalam waktu-waktu yang akan datang sesuai dengan kebutuhan dan keinginannya. Namun penempatan posisi rumah inti sudah dibicarakan dengan penghuni agar bisa mempunyai bayangan kemana akan dikembangkan. Hal ini memang sesuai dengan apa yang disebut oleh Nabeel Hamdi (1991) sebagai fleksibilitas yang disesuaikan dengan kebebasan untuk menentukan atau memilih banyak alternatif dalam pengembangan. Banyaknya variasi pengembangan tidak bisa ditentukan sebagai generalisasi, tetapi harus dilihat kasus per kasus.

Dalam serial penelitian di kompleks perumahan di Yogyakarta (Marsoyo, 1989, 1995, 1997, 2000) menunjukkan bahwa faktor yang menentukan pengembangan rumah adalah bertambahnya jumlah anak dan meningkatnya penghasilan serta legalitas kepemilikan tanah dan rumah. Bila dikaitkan dengan pengembangan rumah inti pasca bencana, maka faktor kepemilikan tanah dan rumah merupakan faktor yang utama, sementara dua faktor lainnya merupakan faktor yang tergantung pada waktu. Proses pengembangan rumah inti dengan pola sedikit demi sedikit (incremental development) ini disesuaikan dengan ketersediaan dana, ruang persil yang masih ada, dan kebutuhan. Adapun proses dan arah pengembangan dapat dilihat pada gambar 3 dan 4.

Social capital sebagai faktor utama percepatan rehabilitasi dan rekonstruksi.

\section{Gambar 3.: Skematik pengembangan rumah inti}

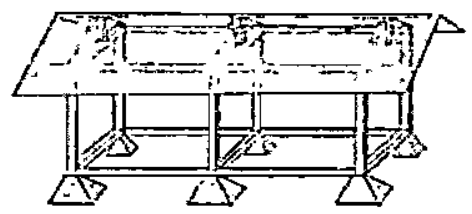

Rumah Int $3 \times 6 \mathrm{mz}$

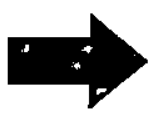
struktur atap dlsesuaikan

Pengembangan l: $6 \times 6 \mathrm{~m} 2$

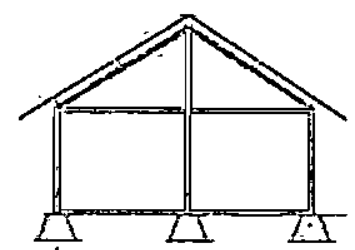
$\longrightarrow$

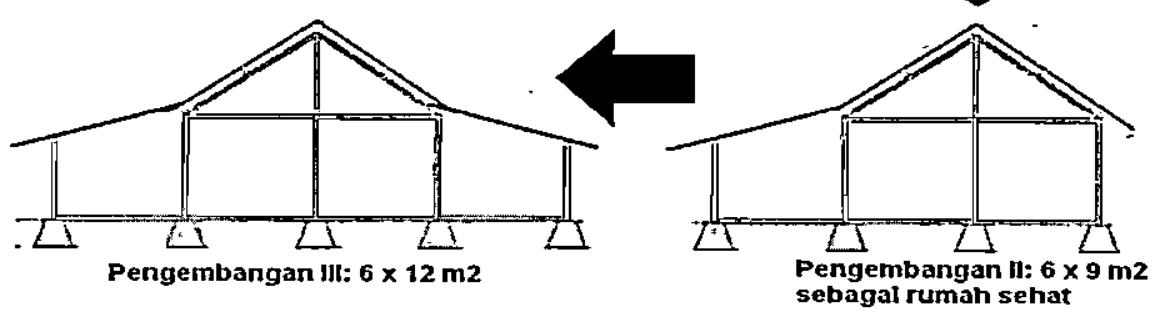

Sumber: Tim PSPPR-UGM, Agustus 2006. 


\section{Gambar 4: Denah Rumah Tumbuh dari Rumah Inti (incremental development)}

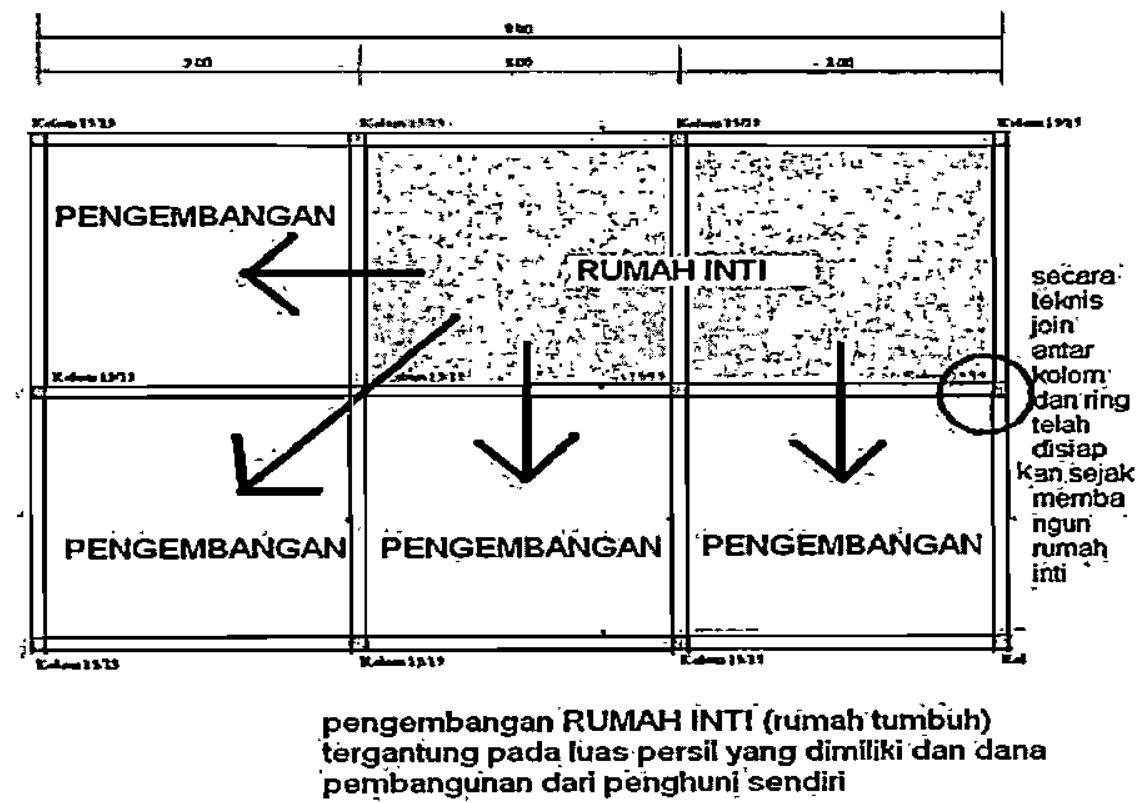

Sumber: TIm PSPPR-UGM, Agustus 2006.

Modal sosial (social capital) merupakan faktor penting dalam manajemen penanganan bencana. Modal sosial ini tidak hanya pada tahap awal saja tetapi dalam proses pemulihan dan pembangunan amat sangat penting untuk dipertimbangkan. Modal sosial oleh Lesser (2000:4) dinyatakan sebagai "..as the wealth (or benefit) that exists because of an individual's social relationship". Sementara itu Coleman (1988) mendefinisikan sebagai hubungan sosial yang memfasilitasi suatu tindakan kolektif dengan mempertimbangkan informasi, pengaruh dan kontrol, dan solidaritas. Dengan modal sosial inilah membangun rumah inti pasca bencana perlu dipraktekkan. Sebenarnya proses membangun rumah atau dalam istilah perumahan sebagai penyediaan rumah (housing delivery) memiliki makna dua hal yakni disediakan oleh pemerintah melalui formal public housing dàn makna yang satu lagi adalah dibangun sendiri oleh masyarakat yang dikenal dengan informal housing. Dalam pembangunan rumah informal inilah kemudian muncul berbagai istilah yakni perumahan sebagai suatu proses (Turner, 1972, 1976; Gilbert, 1983; Laquian, 1983; Ward, 1982; Hamdi, 1991; Tipple, 2000).

Pada sisi lain, membangun (kembali) rumah pada waktu pasca bencana tidak semudah ketika membangun rumah pada waktu normal. Ketika terjadi bencana, maka manajemen secara umum untuk jangka amat sangat pendek adalah untuk tanggap darurat (evakuasi), untuk jangka pendek adalah pemulihan, untuk jangka menengah adalah rehabilitasi dan rekonstruksi, dan jangka panjang adalah perencanaan termasuk evaluasi kritis yang tanggap 
bencana. Masalah yang sering muncul adalah ketika obyek yang ditangani tidak tunggal tapi massal dan area yang dicakup juga luas sementara sumber dana yang ada jumlahnya tidak mencukupi. Untuk itulah dengan modal sosial ini, pembangunan perumahan pasca bencana perlu diterapkan. Pembangunan perumahan inti sampai pengembangan rumah pasca bencana memang memerlukan basis kelompok masyarakat. Kelompok masyarakat yang terkena bencana pada umumnya memiliki hubungan sosial yang kuat dalam membangun kemba!i lingkungannya. Peran partisipasi aktif inilah yang perlu dikembangkan baik pada tahap rehabilitasi dan rekonstruksi sampai pada tahap perencanaan tanggap bencana.

Dalam proses pembangunan rumah inti di Imogiri memang melibatkan masyarakat sebagai penentu kegiatan. Pada tahap awal, lima kepala keluarga membangun rumah inti secara bergantian dengan bantuan per rumah inti sekitar Rp.3.500.000,-. Dengan pendekatan komunitas dijelaskan bahwa adanya bantuan yang serba minim bisa dimanfaatkan untuk membuat shelter (rumah inti) dan bisa sebagai pengganti tenda-tenda. Penjelasan awal bahwa shelter ini bisa dikembangkan di kemudian hari, membuat komunitas di lapangan antusias untuk mewujudkannya. Dengan modal ketrampilan dan kebiasaan gotong-royong yang masih dimiliki di kawasan perdesaan, menjadikan model rumah inti ini mudah diimplementasikan. Di samping itu, komunitas ini diperkenalkan sistem semipabrikasi dengan cetakan beton dari besi baja yang bisa dipergunakan berulang-ulang, sehingga tidak menggunakan perancah beton dari papan yang mudah rusak. Dengan penggunaan cetakan beton menjadikan pembangunan rumah inti bisa digulirkan pada unit berikutnya secara lebih cepat. Pada mulanya memang membutuhkan waktu yang relatif lama, karena komunitas masih mempelajari sistem cetakan beton dan terus diujicobakan untuk mencari cara yang paling cepat. Namun dengan semakin cepatnya pemahaman penggunaan cetakan beton, maka semakin cepat pula pembangunan rumah inti tersebut.

Dengan lima tenaga kerja (dari lima keluarga) dan dengan bantuan bahan bangunan, maka waktu yang dibutuhkan per unit sekitar 5 hari. Pada sisi lain, ibu-ibu dari lima keluarga ini berperan menyediakan minuman dan makanan. Demikian seterusnya sehingga dapat digulirkan pembangunan rumah inti dari kelompok komunitas yang terdiri dari $5 \mathrm{KK}$ ke kelompok komunitas yang lain. Dengan modal sosial, hubungan sosial kekerabatan untuk tindakan rehabilitasi dan rekonstruksi, suatu komunitas di kawasan pedesaan dapat mempercepat proses rehabilitasi dan rekonstruksi pasca bencana.

\section{Penutup}

Pembangunan dan pengembangan rumah inti pada dasarnya mudah dari sisi teknis. Namun bila pembangunan dan pengembangan rumah inti ini menyangkut situasi yang tidak normal, misalnya, pada situasi pasca bencana yang obyeknya massal, tersebar di berbagai lokasi, dengan ekonomi masyarakat yang minim, maka satu-satunya yang masih bisa diandalkan adalah modal sosial (social capital) masyarakatnya apabila di kawasan pedesaan.

Di kawasan perdesaan, yang masih tradisional, masih memegang teguh kegotong-royongan, masih memiliki sikap teposeliro, masih memiliki sikap solidaritas, dapat dengan mudah mengimplementasikan 
konsep pembangunan rumah inti moduler. Dari sini bisa dikatakan bahwa pembangunan rumah inti pasca bencana yang bertumpu pada masyarakat dengan modal sosialnya dapat lebih cepat direalisasikan dengan harapan proses rehabilitasi dan rekonstruksi menjadi lebih cepat.

\section{Dáftar Pustaka}

Abrams, C, 1964. Man's Struggle for Shelter in an Urbanizing World, Cambridge: MIT Press .

Coleman, J.S. 1988. Social capital in the creation of human capital, American Journal of Sociology 94: 95-120.

Gilbert, A. 1983. The Tenants of Self-Help Housing: Choice and Contraint in the Housing Markets of Less Developed Countries, Development and Change: 14.

Habraken, M.J. Boekholt, J. Th., Dinjens, P.J.M., dan Thijssen, A.P., 1976, Variations: The Systematic Design of Support. Cambride:MIT Laboratory of Architecture and Planning.

Hamdi, N., 1991, Housing Without Houses: Participation, Flexibility, Enablement, New York:Van Nostrand Reinhold.

Laquian, A.A., 1983. Basic Housing: Policies for Urban Sites, Services, and Shelter in Developing Countries Ottawa: IDRC.

Lesser, E.L., 2000. Knowledge and Social Capital: Foundations and Applications.Boston:ButterworthHeinemann.
Marsoyo, A. 1989. Hubungan Faktor-faktor Sosial Penghuni dengan Terjadinya Perkembangan pada Rumah Inti di Perumahan Mojosongo Kotamadya Surakarta, Laporan Penelitian DPP UGM, Yogyakarta:FT-UGM.

Marsoyo, A. 1995. Hubungan Faktor SosialEkonomi Penghuni dengan Terjadinya Perubahan Bentuk Rumah di Perumahan Green House Karangkajen Kotamadya Yogyakarta. Laporan Penelitian DPP UGM, Yogyakarta: FTUGM.

Marsoyo, A. 1997. Hubungan Faktor SosialEkonomi dengan Terjadinya Perubahan Bentuk Rumah di Griya Arga Permai di Kabupaten Sleman, Laporan Penelitian DPP UGM, Yogyakarta: FT-UGM, .

Marsoyo, A. 2000. Hubungan Faktor SosialEkonomi dengan Terjadinya Perubahan Bentuk Rumah di Griya Ketawang Indah di Kabupaten Sleman, Laporan Penelitian DPP UGM, Yogyakarta:FT-UGM.

Patton, C. (ed), 1988. Spontanoues Shelter: International Perspectives and Prospects, Philadelphia:Temple University Press, .

Sinai, I. 2002. The determinants of the number of rooms occupied by compound dwellers in Kumasi, Ghana: does working at home mean more rooms?, Applied Geography 22: 77-90.

Tipple, G. 1996. Housing Extensions as Sustainable Development, Habitat international 20, 3: 367-376. 
Rumah Inti Untuk Percepatan Rehabilitasi dan Rekonstruksi Pasca...Agam Marsoyo

Tipple, G. 2000. Extending themselves: user-initiated transformations of government-built housing in developing countries, Liverpool:Liverpool University Press.

Turner, J.F.C. 1972. Housing as a Verb, in Freedom to Build: Dweller Control of the Housing Process edited by John
F Turner and Robert Fichter, New York:McMillan.

Turner, J.F.C. 1976. Housing by People, London:Marion Boyars.

Ward, P. M. (ed), 1982. Self-Help Housing: A Critique, London:Mansell. 